Ulyan Khalif. 2017. Pengaruh Penanaman Sengon (Paraserianthes falcataria) Terhadap Kandungan C Dan N Tanah Di Desa Resapombo, Doko, Blitar Journal Viabel Pertanian. (2018), 12(1) 49-59

\title{
PENGARUH PENANAMAN SENGON (Paraserianthes falcataria) TERHADAP KANDUNGAN C DAN N TANAH DI DESA RESAPOMBO, DOKO, BLITAR
}

\author{
Ulyan Khalif, S.P., M.Sc. ${ }^{1}$ \\ ${ }^{1}$ Badan Pertanahan Nasional/Kantor Pertanahan Kabupaten Blitar \\ email: uyankhalif@gmail.com
}

\begin{abstract}
Landuse change are suspected to be one responsible to soil fertility decline on Resapombo, Doko, Blitar. Efforts done by local farmers to deal with these problems are plantation of $P$. falcataria trough a reforestation program around 2011-2012. The benefits of the program are still need to be assessed so that this research was done (1) to compare the soil quality between $P$. falcataria-planted field and no P.falcataria field by the parameters of soil organic matter content and available $N$, (2) to study the relationship between organic matter input and soil organic matter content and available $N$, and (3) to identify factors affecting $N$ availability post-P. falcatariaplantation. This research used randomized block design with 5 treatments (annual crop field, 3 and 6 years $P$. falcaria plantation field, agroforestry field with $P$. falcataria + coffee + talas plantation, and ex-P. falcataria-planted field. Soil were sampled compositely by 3 replication from 0-20 cm depth. Litter were sampled from a $0.5 \mathrm{~m} 2$ sub-plot of each treatment. Results showed that $P$. falcataria plantations enhance soil fertility indicated by increased soil organic matter input to 10.6 times (monoculture) and 17.6 times (agroforestry) control, increased soil organic matter content by 1.5 times (monoculture) and 2.3 times(agroforestry) control, increased total $N$ of 1.6 times (monoculture) and 2.4 times (agroforestry) control, increased ammonium by 1.7 times (monoculture) and 3.2 times (agroforestry) control, and increased nitrate by 2.4 times (monoculture) and 3.9 times(agroforestry) control.The increased soil $N$ content of $P$. falcataria-planted field were caused by higher soil organic inputs compared to those with no $P$. falcataria plantation. Nitrogen availability affected by soil texture but have no relationship with soil pH. However, agroforestry fields showed higher $\mathrm{pH}$, organic $\mathrm{C}$, total $\mathrm{N}$, and available $N$ than monoculture $P$. falcataria fields. Measured soil chemical properties showed no significant change by the increase of $P$. falcataria age, moreover, they declined down towards control on ex-P. falcatariaplantation. This indicates that reforestation would only give a temporary soil quality enhancement.
\end{abstract}

Key words: Regreening, Paraserianthes, Agroforestry, Soil organic matter, nitrogen total 


\section{PENDAHULUAN}

Penurunan kualitas kesuburan tanah akibat alih guna lahan untuk praktek pertanian intensif telah menjadi suatu permasalahan bagi petani Desa Resapombo, Doko, Blitar.Berdasarkan pengamatan di lapangan, upaya perbaikan yang telah dilakukan petani setempat adalah dengan menanam pohon sengon (Paraserianthes falcataria) melalui program penghijauan pada tahun 2011-2012. Disamping lebih menguntungkan dari sektor ekonomi, tanaman sengon juga memberikan beberapa kontribusi bagi tanah salah satunya dari segi masukan hara. Beberapa petak penanaman sengon di Desa Resapombo pada tahun 2017 telah memasuki masa tebang.Sebagian lahan pasca penebangan sengon digunakan untuk penanaman kembali tanaman semusim seperti ubi kayu yang berdasarkan pengamatan dan penilaian secara kualitatif dari petani setempat, pertumbuhannya dinilai lebih baik dibandingkan saat penanaman sebelum penghijauan dengan tanaman sengon. Menurut Orwa et al. (2009), sengon merupakan tanaman legum yang melalui jatuhan seresah dan rantingnya mampu memberikan masukan $\mathrm{N}$, bahan organik, serta berbagai mineral bagi lapisan permukaan tanah. Berdasarkan fakta dan pernyataan tersebut muncul dugaan bahwa terjadi perbaikan kesuburan tanah untuk lahan-lahan yang telah ditanami sengon.

Manfaat penghijauan tersebut masih perlu dikaji sehingga dilakukan penelitian ini, dengan tujuan mengetahui dan membandingkan kualitas kesuburan tanah pada lahan yang ditanami sengon dengan lahan tanpa penanaman sengon ditinjau dari parameter kandungan bahan organik tanah dan $\mathrm{N}$ tersedia, hubungan antara masukan bahan organik dengan kandungan bahan organik tanah serta $\mathrm{N}$ tersedia dalam tanah, serta faktor-faktor yang mempengaruhi ketersediaan $\mathrm{N}$ tanah dalam hubungannya dengan penanaman sengon.

\section{Bahan dan Metode}

Penelitian dilaksanakan di Desa Resapombo, Kecamatan Doko, Kabupaten Blitar. Kegiatan survey lapangan dimulai pada bulan Februari 2010 dilanjutkan pengambilan sampel hingga analisis tanah hingga Juni 2010.Analisis tanah dilakukan di Laboratorium Kimia Tanah Jurusan Tanah, Fakultas Pertanian, Universitas Brawijaya, Malang.

\section{Penentuan Plot dan Pengambilan Sampel}

Plot pengamatan terdapat pada berbagai sistem pola penanaman sengon di Desa Resapombo serta lahan non-sengon (tanaman semusim) sebagai kontrol. Terdapat lima macam faktor perlakuan dalam penelitian, meliputi: lahan tanaman semusim (TS), lahan sengon monokultur dengan usia tanam 3-4 tahun (S3), lahan sengon monokultur dengan usia tanam 5-6 tahun (S6), lahan sengon dengan sistem pola tanam agroforestri sengon + kopi + talas (SAF), dan lahan bekas penanaman sengon/lahan sengon pasca tebang (SX). Pada tiap-tiap faktor perlakuan terdapat 3 plot pengamatan yang juga diperlakukan sebagai ulangan. Titiktitik pengamatan pada tiap faktor perlakuan tersebar pada kelas kelerengan yang sama (3-8\%) dan jenis bahan induk yang sama (Qpg).

Pengambilan sampel meliputi pengambilan contoh tanah dan contoh seresah. Pengambilan contoh tanah dilakukan secara komposit dari tiga titik pengambilan sampel pada kedalaman 0 $-20 \mathrm{~cm}$ untuk tiap plot. Contoh tanah digunakan untuk analisis kandungan bahan organik 
dan $\mathrm{N}$ - total serta $\mathrm{N}$ - mineral tanah. Khusus penanganan sampel untuk $\mathrm{N}$ - mineral, contoh tanah disimpan dalam coolbox untuk menjaga dari penguapan. Sampel tanah utuh diambil menggunakan ring sampel pada kedalaman yang sama untuk pengukuran berat isi tanah sedangkan pengeboran tanah dilakukan untuk analisis kadar air sehingga dapat diketahui kelembaban tanah pada lokasi pengambilan sampel. Pengukuran kelembaban tanah dilakukan secara periodik yaitu tiap dua hari dalam kurun waktu satu hingga dua minggu. Terdapat 5 faktor perlakuan yang diajukan dalam penelitian dan terdapat 3 plot untuk tiap faktor perlakuan tersebut yang juga diperlakukan sebagai ulangan sehingga total keseluruhan contoh tanah yang diambil adalah 15 sampel.

Pengamatan dan pengambilan contoh seresah dilakukan pada tiap faktor perlakuan pada subpetak dengan ukuran 0,5 meter x 0,5 meter. Pengamatan dan pengambilan contoh seresah meliputi daun dan ranting tanaman yang belum membusuk dan terdekomposisi.

\section{Analisis Laboratorium}

Pada tahap analisis laboratorium contoh tanah dianalisis kandungan C-organik (Walkey dan Black), $\mathrm{N}$ total dan $\mathrm{N}$ tersedia (Kjehldal), $\mathrm{pH}$ (elektroda), tekstur (pipet) dan kelembabannya (gravimetri). Nilai C-organik tanah yang didapat akan dikonversi menjadi nilai kandungan bahan organik tanah (\%) dengan persamaan:

$$
\% \text { BOT }=\frac{100}{58} \times \% \text {-org }
$$

Contoh seresah dihitung berat seresah (destruktif) dan dianalisis kandungan C-organik seresah (Wakley\&Black) serta $\mathrm{N}$ total seresah (Kjehldal).

\section{Analisis Data}

Analisis data menggunakan uji sidik ragam (F) untuk mengetahui pengaruh perlakuan terhadap parameter. Untuk mengetahui perbedaan antar perlakuan digunakan uji BNT 5\%.Uji korelasi digunakan untuk mengetahui derajat keeratan antar du a parameter.Apabila antar dua parameter menunjukkan hubungan yang erat maka dilanjutk an dengan analisis regresi untuk mengetahui pengaruh parameter independen terhadap param eter dependen.

\section{Hasil dan Pembahasan}

\section{Hasil}

\section{Tekstur Tanah}

Tekstur tanah pada lokasi $\mathrm{p}$ enelitian didominasi oleh kelas lempung dan lem pung berliat.Variasi signifikan antar faktor perlakuan terdapat pada proporsi partikel pasir dan liat (Gambar 1). 


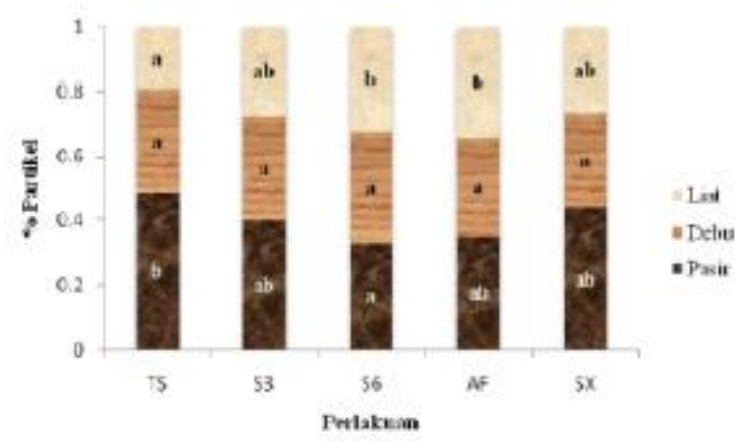

Gambar 1. Perbandingan Proporsi Pasir, Debu, dan Liat pada Masing Masing Faktor Perlakuan.

\section{Kemasaman Tanah}

Nilai $\mathrm{pH}$ tanah bervariasi antar faktor perlakuan dengan nilai te rendah pada lahan sengon 3 tahun (5.97) dan tertinggi pada lahan Agroforestri (6.25) (Gambar 2).

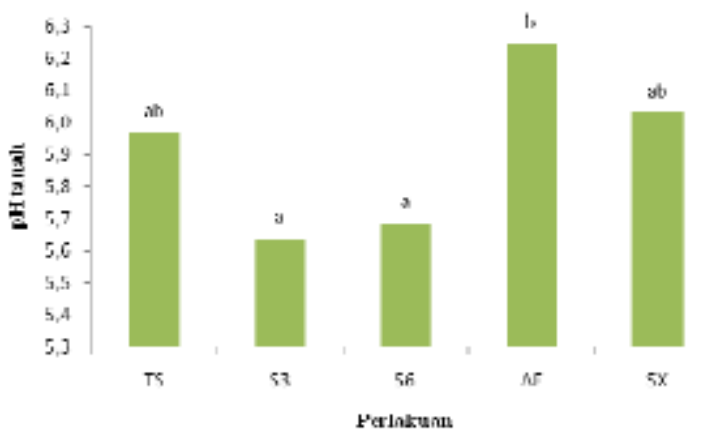

Gambar 2. Perbandingan pH Tanah pada Masing-Masing Faktor Perlakuan.

\section{Kelembaban Tanah}

Pendekatan dalam penentuan kelembaban tanah dapat dilakukan deng an membandingkan kadar air per jumlah ruang pori dalam tanah sehingga didapat jumlah pori terisi air/waterfilled pore space (WFPS) se perti dinyatakan oleh Robertson et al. (2007). Perhitungan jumlah pori terisi air menggunak an referensi kadar air gravimetri (g air g-1 tanah kering oven) dan berat isi tanah dengan persamaan:

$$
\% \text { WFPS }=\frac{\text { K.A. grav. } \times \text { B.I. } \operatorname{tanah} \times 100}{1-\text { (B.I. } \tan a h / 2 \cdot 65)}
$$




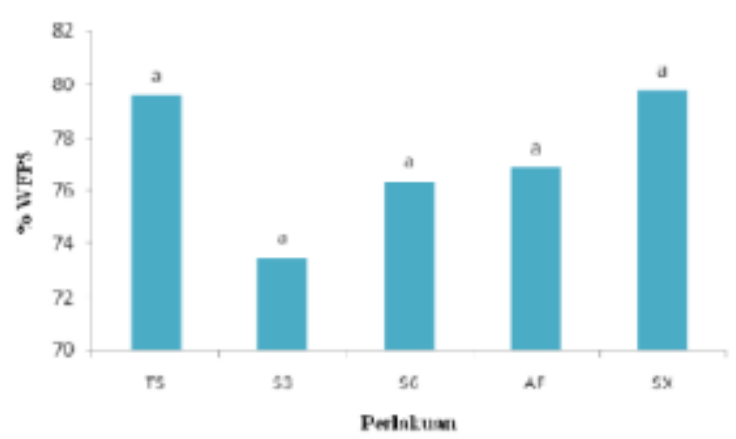

Gambar 3. Perbandinga n Kelembaban Tanah (\%Water-Filled Pore Space/WFPS) pada Masing-Masing Faktor Perlakuan.

\section{Masukan Bahan Organik dan Kandungan Bahan Organik Tanah}

Masukan seresah tertingg i terdapat pada lahan agroforestri (7.32 t ha-1) dan terendah pada lahan semusim (0.42 t h a-1) serta lahan pasca tebang (0.47 t ha-1) (Gam bar 4). Rata-rata nilai penambahan bahan organ ik adalah sebesar $4.01 \mathrm{t}$ ha-1 untuk sengon mo nokultur sedangkan untuk agroforestri sengon mencapai $6.91 \mathrm{t}$ ha-1, sehingga nilai masukan bahan organik menjadi 10.6 kali nilai kontrol untuk lahan sengon monokultur dan 17.6 kali nilai kontrol untuk lahan agroforestri sengon.

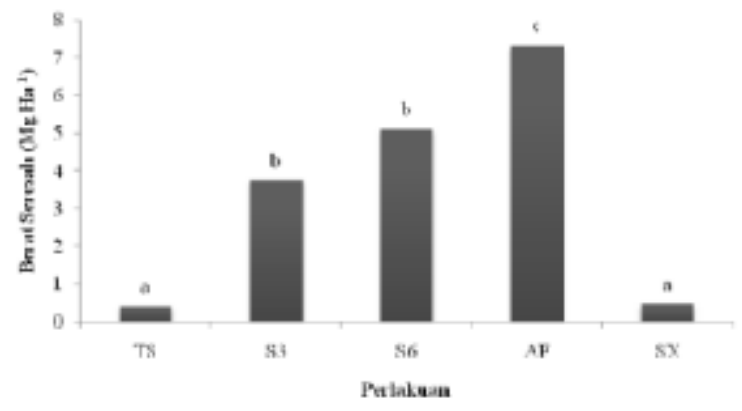

Gambar 4. Perbandingan Berat Seresah pada Masing-Masing Faktor Perlakuan.

Sejalan dengan jumlah masukan bahan organik, hasil analisis kandungan bahan organik tanah menunjukkan nilai tertinggi terdapat pada lahan agroforestri $(3.57 \%)$, sedangkan terendah pada lahan semusim (1.53\%). Penanaman sengon dengan sistem tanam monokultur meningkatkan kandungann bahan organik rata-rata senilai $0.68 \%$ menjadi 1.5 kali nilai kontrol, sedangkan dengan sistem agroforestri, peningkatannya mencapai $2.04 \%$ menjadi 2.3 kali nilai kontrol. (Gambar 5). 


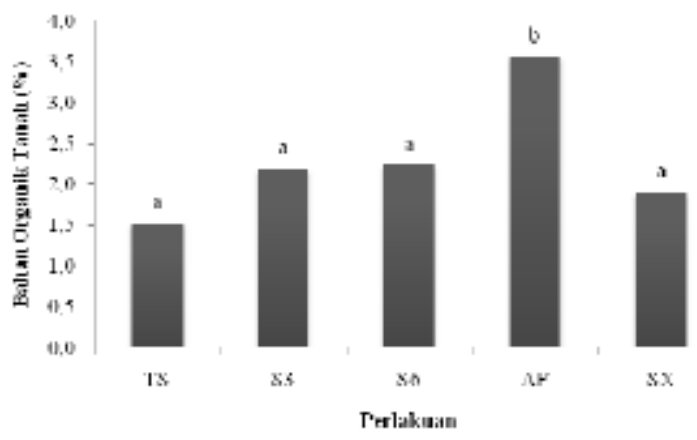

Gambar 5. Perbandingan Kandungan Bahan Organik Tanah pada Masing-masing Faktor Perlakuan.

Perbedaan kandungan bahan organik pada tiap faktor perlakuan disebabka $\mathrm{n}$ karena perbedaan jenis dan jumlah masukan seresah ke dalam tanah. Pada penelitian ini didapati bahwa masukan bahan organik maupun kandungan bahan organik tidak berbe da jauh antara lahan sengon usia 3 tahun dengan 6 tahun, namun nilai keduanya masih lebih rendah dibandingkan pada laha $\mathrm{n}$ agroforestri dan bahkan mengalami penurunan mendekati kontrol pada lahan pasca tebang.

\section{Nitrogen Tanah}

Hasil penelitian menunjukkan kandungan nitrogen yang lebih tinggi dengan perbedaan yang tidak signifikan pada lahan yang ditanami sengon dibandingkan dengan lahan semusim (Gambar 6).

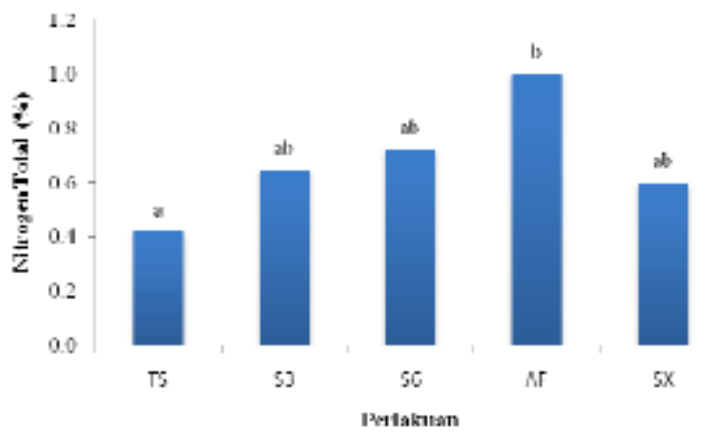

Gambar 6. Perbandingan N Total pada Masing-Masing Faktor Perlakuan.

Kandungan nitrogen total tertinggi terdapat pada lahan agroforestri (1.00\%) sedangkan terendah terdapat pada laha $\mathrm{n}$ semusim $(0.42 \%)$. Penanaman sengon mono kultur meningkatkan $\mathrm{N}$ total tanah pada lokasi penelitian sebesar rata-rata $0.27 \%$ sedangkan dengan sistem agroforestri, nilai peningkatan $\mathrm{N}$ total tanah adalah $0.58 \%$. Akibat peningkatan tersebut, kandungan $\mathrm{N}$ total pada lahan sengon monokultur meningkat menjadi 1.6 kali nilai kontrol sedangkan pada lahan agroforestri menjadi 2.4 kali nilai kontrol. 
Jumlah $\mathrm{N}$ tersedia ( $\mathrm{NH}^{+}$dan $\mathrm{NO}^{-}$) pada masing-masing faktor perlakuan ditunjukkan pada Gambar 7. Kadar ammonium dan nitrat tertinggi terdapat pada lah an agroforestri (37.60 ppm dan 42.94 ppm) sedangkan terendah pada lahan semusim (11.48 pp m dan 10.98 ppm).

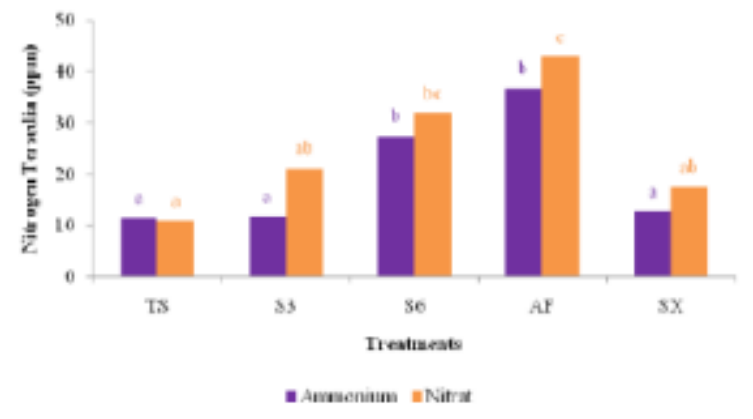

Gambar 7. Perbandingan N Tersedia pada Masing-Masing Faktor Perlakuan.

Kandungan ammonium dalam tanah meningkat menjadi $1.7 \mathrm{k}$ ali nilai kontrol pada lahan sengon monokult ur dan 3.2 kali nilai kontrol pada lahan agroforestri sengon. Kandungan nitrat meningkat menjadi 2.4 kali nilai kontrol pada lahan sengon monokultur dan 3.9 kali nilai $\mathrm{k}$ ontrol pada lahan agroforestri sengon.Berda sarkan uji sidik ragam kelima faktor perlakuan berpengaruh nyata terhadap kandungan $\mathrm{N}$ tersedia dalam tanah.

\section{Pembahasan}

\section{Masukan Bahan Organik dan Hubungannya dengan Kandungan Bahan Organik.}

Kualitas kesuburan tana h dapat ditinjau salah satunya dari segi kandu ngan bahan organik tanah serta ketersediaan nitrogen dalam tanah. Masukan seresah yang tinggi akan menguntungkan kare na meningkatkan kandungan bahan organik dalam tanah yang berperan sebagai salah satu sumber nitrogen bagi tanah. Gambar $8 \mathrm{~m}$ enunjukkan hubungan antara berat kering sere sah (masukan bahan organik) dengan kadar bahan organik tanah. Semakin tinggi masukan bahan organik maka kandungan bahan organik tanah juga akan semakin tinggi $(\mathrm{R} 2=0.81)$.

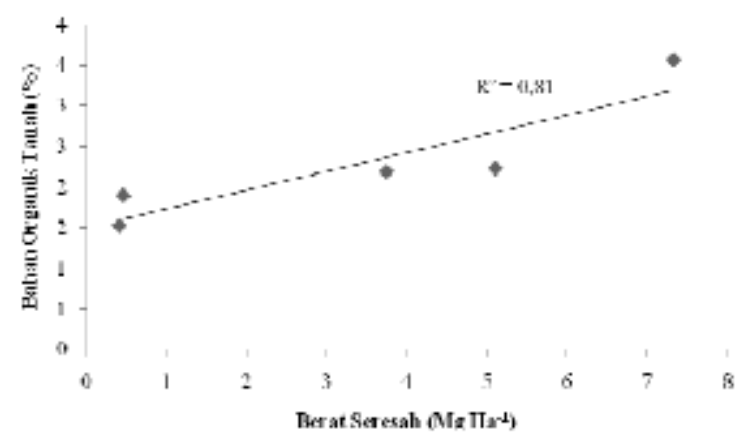

Gambar 8. Hubungan an tara Berat Kering Seresah dengan Kandungan Bahan Organik Tanah. 
Ulyan Khalif. 2017. Pengaruh Penanaman Sengon (Paraserianthes falcataria) Terhadap Kandungan C Dan N Tanah Di Desa Resapombo, Doko, Blitar Journal Viabel Pertanian. (2018), 12(1) 49-59

\section{Hubungan Bahan Organik dengan N Total maupun N Tersedia pada Lokasi Penelitian}

Kandungan bahan organik tanah diasumsikan sebagai sumber utama $\mathrm{N}$ tanah pada lokasi penelitian. Jenis penggu naan lahan yang memiliki kandungan bahan organik tanah yang tinggi akan memiliki kandu ngan $\mathrm{N}$ tanah yang tinggi pula (Gambar 9 dan 10).

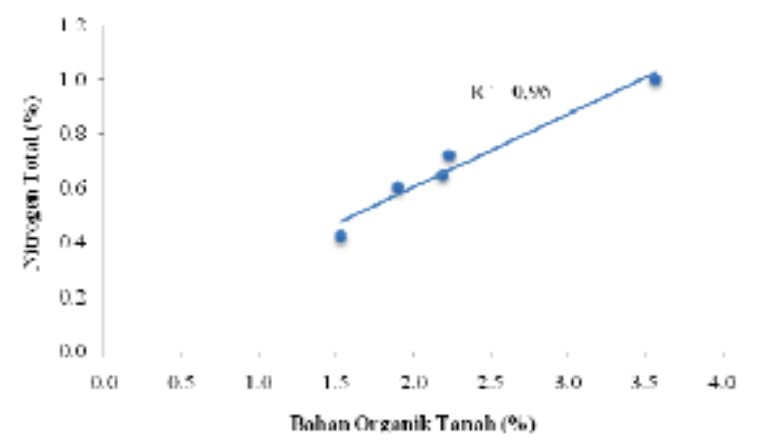

Gambar 9. Hubungan antara Kandungan Bahan Organik Tanah dengan N Total.

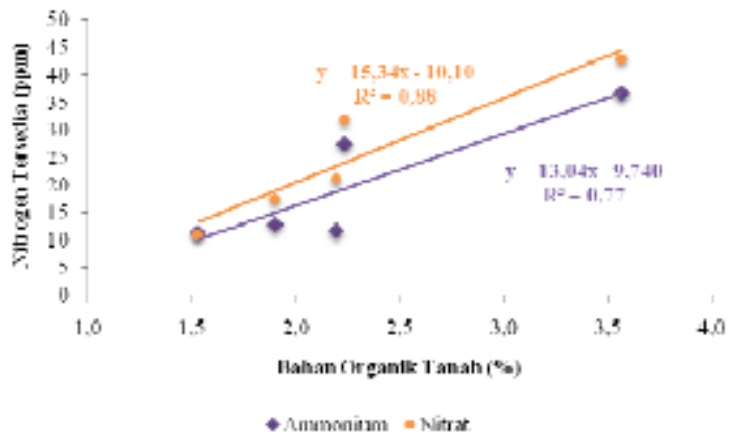

Gambar 10. Hubungan a ntara Kandungan Bahan Organik Tanah dengan N Tersedia.

Pengaruh Parameter Pendukung-Tekstur, pH, dan Kelembaban Tanah-Terhadap N Nanah pada Lokasi Penelitian.

Tekstur tanah menunjukka $\mathrm{n}$ adanya hubungan korelatif terhadap ammonium dan nitrat terutama pada proporsi pasir dan liat, sedangkan $\mathrm{pH}$ dan kelem baban tanah tidak berpengaruh signifikan terhadap $\mathrm{N}$ tersedia pada lokasi penelitian.

Tekstur tanah berperan kuat dalam dinamika $\mathrm{N}$ dan $\mathrm{C}$ dala $\mathrm{m}$ tanah (Matus et al., 2008). Hasil analisis menunjukkan adanya pengaruh perbedaan proporsi partikel yang cukup nyata terhadap kandungan bahan organik tanah pada faktor perlakuan pada taraf 5\%.Semakin tinggi jumlah liat akan diikuti peningkatan $\mathrm{N}$ tersedia ( $\mathrm{R} 2=0.80$ ). Sebaliknya, peningkatan proporsi pas ir akan menyebabkan penurunan $\mathrm{N}$ tersedia ( $\mathrm{R} 2=0.77)$ (Gambar $11 \& 12)$. 


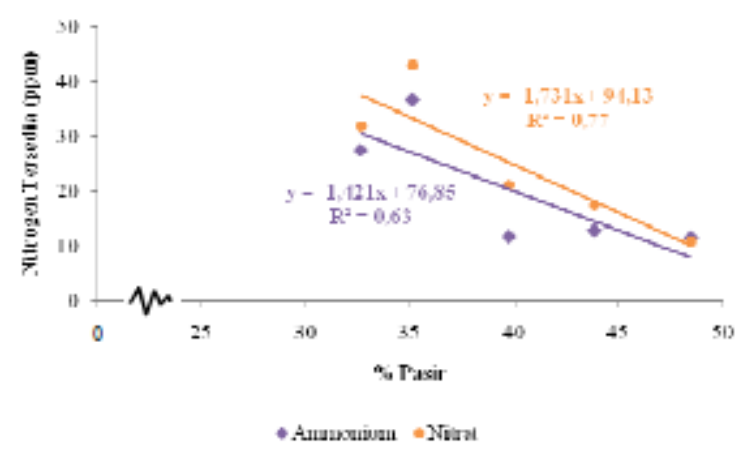

Gambar 11. Hubungan antara Proporsi Pasir dengan N Tersedia.

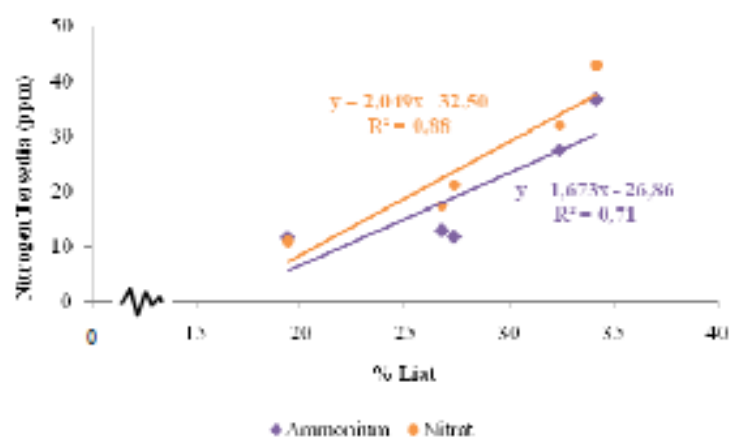

Gambar 12. Hubungan antara Proporsi Liat dengan N Tersedia.

Hasil analisis $\mathrm{pH}$ pada masing-masing faktor perlakuan tidak menunj ukkan korelasi yang nyata dengan parameter $\mathrm{N}$ tersedia.Hal ini dapat disebabkan karena walaupun berbeda nyata antar perlakuan namun secara keseluruhan masih termasuk dalam kriteria $\mathrm{pH}$ sedang (5.56.5) menurut LPT (1983) sehingga kisarannya dapat dikatakan masih relatif homogen.

Kelembaban tanah dalam hubungannya dengan ketersediaan $\mathrm{N}$ tanah dianalogikan sebagai jumlah pori terisi air/water-filled pore space (WFPS). Pada kond isi tertentu, kadar air dan aerasi dapat menjadi faktor pembatas terhadap laju mineralisasi, nitrifikasi, dan denitrifikasi sehingga jumlah ruang pori yang terisi air merupakan faktor yang berperan langsung terhadap transformasi $\mathrm{N}$ dalam tanah terutama yang berhubungan dengan aktivitas bakteribakteri nitrogen (Zhang et al., 2002 \& Robertson et al., 2007). Kadar air yang lebih tinggi pada lahan semusim dan pasca tebang diduga menyebabkan kekahatan udara menjadi faktor pembatas dalam mineralisasi N seperti dinyatakan oleh Robertson (2007), pada kondisi pori terisi air sebanyak $60 \%$, laju mineralisasi menurun dan pada kondisi $80 \%$ mulai terjadi denitrifikasi.

\section{Pengaruh Penanaman Sengon terhadap Kualitas Kesuburan Tanah}

Tanaman pohon dari jenis legum dapat berperan penting sebagai sumber nitrogen bagi tanah dan dapat dipertimbangkan sebagai sumber nitrogen yang lebih murah dan ramah lingkungan.Dalam berbagai penelitian (Parotta, 1990; Santoso, 2000; Chintu et al.,2004 \& 2008; dan Zaharah et al., 2008) Paraserianthes falctaria atau sengon yang juga termasuk 
golongan tanaman legum telah dinyatakan mampu meningkatkan $\mathrm{N}$ tersedia dalam tanah dan hal ini sesuai dengan hasil penelitian di Desa Resapombo.

Tinggi-rendahnya kandungan $\mathrm{N}$ tanah dipengaruhi oleh jumlah masukan maupun kehilangan dalam siklus N. Masukan N dapat bersumber dari pelapukan bahan organik (Syekhfani, 1997) yang salah satunya dapat berasal dari seresah tanaman. Kehilangan N dapat terjadi melalui penyerapan oleh tanaman maupun pencucian dan erosi (Barbarick, 2006). Rendahnya kandungan $\mathrm{N}$ pada lahan dengan tanpa penanaman sengon dapat disebabkan karena masukan hara yang lebih kecil dan jumlah kehilangan yang besar. Kehilangan N pada lahan semusim dapat disebabkan oleh tingginya tingkat penguapan dan pencucian akibat kurangnya tutupan lahan, juga karena $\mathrm{N}$ terkandung dalam tanaman yang ikut terangkut hasil panen sehingga tidak ada siklus pengembalian $\mathrm{N}$ ke dalam tanah.

Peningkatan produksi ketela pada lahan pasca tebang secara kualitatif tidak berhubungan dengan perbedaan kualitas kesuburan tanah antara lahan semusim dengan lahan pasca tebang. Walaupun terdapat peningkatan $\mathrm{N}$ yang signifikan pada lahan pasca tebang bila dibandingkan dengan lahan semusim, perbedaan kandungan $\mathrm{N}$ diduga tidak akan berlangsung untuk waktu yang lama. Hasil analisis dinamika pelepasan $\mathrm{N}$ dari residu $P$. falcataria oleh Chintu et al. (2004) menunjukkan bahwa peningkatan $N$ mineral hanya bertahan pada periode awal inkubasi hingga kemudian terdapat penurunan secara bertahap menurut fungsi waktu. Hal ini menunjukkan bahwa perlu adanya masukan $\mathrm{N}$ dari luar secara berkelanjutan untuk menjaga dari kekahatan karena $\mathrm{N}$ dalam tanah merupakan unsur dengan mobilitas yang tinggi.

Sistem penanaman sengon dengan pola agroforestri dapat menunjang kualitas kesuburan tanah yang paling baik.Kandungan $\mathrm{N}$ dalam tanah pada lahan agroforestri merupakan yang tertinggi diantara kelima faktor perlakuan sebagai pengaruh dari tingginya bahan organik tanah.Pola tanam agroforestri memiliki tutupan lahan yang relatif rapat sehingga meminimalisir kehilangan $\mathrm{N}$ akibat pencucian maupun penguapan, serta menahan energi pukulan air hujan sehingga menghambat laju eluviasi partikel liat yang berperan terhadap jerapan hara.

\section{Kesimpulan}

Hasil penelitian menunjukkan bahwa penanaman sengon pada lokasi penelitian meningkatkan kualitas kesuburan tanah diindikasikan dari adanya peningkatan masukan bahan organic, kandungan bahan organik tanah, $\mathrm{N}$ total, serta $\mathrm{N}$ tersedia.Adanya peningkatan $\mathrm{N}$ tanah pada lahan dengan penanaman sengon disebabkan karena masukan bahan organik yang lebih tinggi dibandingkan dengan lahan tanpa penanaman sengon.Kandungan $\mathrm{N}$ tersedia dipengaruhi oleh tekstur tanah tetapi tidak berhubungan dengan nilai pH.Meskipun demikian, lahan dengan sistem tanam agroforestri memiliki nilai $\mathrm{pH}, \mathrm{C}$-organik, $\mathrm{N}$ total, dan $\mathrm{N}$ tersedia yang lebih tinggi dibandingkan dengan sengon monokultur. Sifat kimia yang terukur tidak mengalami perubahan yang nyata seiring dengan pertambahan usia sengon, bahkan menurun mendekati kontrol pada lahan pasca tebang. Hal ini menunjukkan dari segi kualitas kesuburan tanah, penghijauan dengan tanaman pohon/hutan produksi hanya memberikan dampak sementara oleh karena itu penanaman sengon di Desa Resapombo sebaiknya dilakukan dengan menggunakan sistem agroforestri. 
Ulyan Khalif. 2017. Pengaruh Penanaman Sengon (Paraserianthes falcataria) Terhadap Kandungan C Dan N Tanah Di Desa Resapombo, Doko, Blitar Journal Viabel Pertanian. (2018), 12(1) 49-59

\section{Daftar Pustaka}

Barbarick K. A. 2006. Nitrogen Sources and Transformations.Colorado State University.U.S. Department of Agriculture and Colorado counties cooperating.

Chintu, R., Zaharah, A.R., and Rasidah, A.K.W. 2004.Decomposition and Nitrogen Release Patterns of Paraserianthes falcataria Tree Residues under Controlled Incubation. Agroforestry Systems 63: 45-52. Kluwer Academic Publishers. Netherlands.

Chintu,R., Matakala, P.M., and Zaharah, A.R., 2008. Decomposition and Nitrogen Mineralization of Leaves of Paraserianthes falcataria in an Ultisol under Field Conditions.In: Management of Agroforestry Systems for Enhancing Resource use Efficiency and Crop Productivity, page: 221-231. IAEA. Austria.

LPT. 1983. Kriteria Penilaian Sifat Kimia Tanah. Jurusan Tanah, Fakultas Pertanian, Universitas Brawijaya, Malang.

Matus, F.J., Lusk, C.H., and Maire, C.R. 2008. Effect of Soil Texture, Carbon Input Rates, and Litter quality on Free Organic Matter and Nitrogen Mineralization. Communications in Soil Science and plant Analysis, 39: 187-201.

Orwa, C., Mutua, A., Kindt, R., Jamnadass, R., Anthony, S. 2009. Agroforestree Database: a tree reference and selection guide version 4.0, diakses dari http://www.worldagroforestry.org/sites/treedb s/treedatabases.asp pada tanggal 2 Januari 2010.

Parotta, J.A. 1990. Paraserianthes falcataria (L.) Nielsen - Batai, Moluccan sau. SO-ITF-SM31.

Robertson, G.P., and Groffman, P.M. 2007. Nitrogen Transformations.E.A. Paul, ed. Soil Microbiology, Biochemistry, and Ecology. Springer, New York, New York, USA, pp. 341-364.

Santoso, B. 2000. Studi Analisis Tanah, Daun, dan Seresah Tanaman Sengon (Albizia falcataria L.) pada Jenis Tanah Hapludalf di PT. Perkebunan Nusantara XII (Persero) Pancursari, Malang. Habitat Vol. 11 No. 111 : 76-91.

Syekhfani. 1997. Hara-Air-Tanah-Tanaman. Jurusan Tanah Fakultas Pertanian Universitas Brawijaya. Malang.

Zaharah, A.R., Chintu, R., Ziana, Z.Z., Bah, A.R., and wan Rashidah, W.A.K. 2008.Relative Contribution of Hedgerow Leguminous Trees, Leaf Mulch and Supplementary Urea to the Yield and N Nutrition of Alley Maize Crops.In: Management of Agroforestry Systems for Enhancing Resource use Efficiency and Crop Productivity : 15-28. IAEA. Austria.

Zhang, R., and Wienhold, B.J. 2002. The Effect of Soil Moisture on Mineral Nitrogen, Soil Electrical Conductivity, and pH. Agroecosystems 63:251-254. Kluwer Academic Publishers. Netherlands 